\title{
Approaches to Advising Incoming College Students with Dual Enrollment Credit
}

Patricia Witkowsky, Ph.D. , Assistant Professor, Leadership, Research, and Foundations University of Colorado Colorado Springs

Martin Garnar, MA, MLIS Dean and Professor, Kraemer Family Library, University of Colorado Colorado Springs

Kathryn Starkey, MA, Adult Learning Lead Specialist, Extended Studies, Colorado State University Pueblo

Ashley Andersen, MA, Pathway Advisor, Advising \& Counseling, Saint Paul College

Grant Clayton, Ph.D., Assistant Professor, Teaching and Learning, University of Colorado Colorado Springs

Study approved by the University of Colorado Colorado Springs Institutional Review Board. IRB Approval 18-083.

Study funded by a NACADA: The Global Community for Academic Advising Research Grant in January 2018.

Academic advisors in higher education are often incoming students' first exposure to college curriculum and academic expectations. Additionally, academic advisors serve as an ongoing support to students throughout their college careers. As the number of students beginning college full-time with a significant amount of dual enrollment (DE) credits increases, academic advisors must develop approaches to advising this population of students based on academic and developmental needs. This study explored the approaches college academic advisors take when advising high DE creditbearing incoming college students. 


\section{Introduction}

Although completing academic coursework is the only documented requirement to receive a college degree, there is value in the psychosocial, cognitive, and identity development that occurs in the college environment, as is evidenced by the co-curricular and leadership opportunities available in college (Patton, Renn, Guido, \& Quaye, 2016). Students who have successfully completed college creditbearing opportunities available in high school to their fullest capacity are able to enter college directly from high school with up to a two-year degree, requiring only two additional years as a full-time college student to graduate. Although dual enrollment (DE) students are arriving on campus with signs of academic success (An, 2013; Smith \& Garton, 2008), academic advisors are concerned about the developmental outcomes of a college education that occur beyond the completion of academic requirements.

Most DE research focuses on the outcomes and impacts of student participation in those programs and courses (An, 2013; Daly, 2009; Smith \& Garton, 2008). However, this study is unique in its use of a constructivist methodology and qualitative methods to explore the experiences of college academic advisors working with high DE credit-bearing, incoming college students and the approaches to advising those students given advisors' philosophies about the holistic college experience, young adult development, and career preparation.

The following research questions guided the study:

1) What do college academic advisors perceive as the purpose of higher education and their role in it?

2) How do college academic advisors utilize their philosophy of higher education when advising high dual credit-bearing incoming college students?

3) How do college academic advisors utilize their knowledge of developmental theory to inform their advising practices with high dual credit-bearing incoming college students?

There are various models of academic advising and while this study 
sought to understand how professional academic advisors approach advising high DE credit-bearing incoming students, the findings and approaches will also benefit faculty advisors at institutions with faculty or collaborative advising models.

\section{Literature Review}

\section{Role of Academic Advisors in Developmental Advising}

Academic advisors play an integral role in the success of students as they transition to college. Various organizations have lists outlining the responsibilities of the advising profession, which include advising students, disseminating information, developing programming, serving as a liaison between departments, and developing students (McMahan, 2008). In addition to helping students select classes that lead toward degree completion, advisors are crucial for helping students think about the larger purpose of higher education, which leads advisors to consider various advising methods. Developmental advising, as one method, is a multifaceted practice that takes a different approach than prescriptive advising (Bland, 2003; White \& Schulenberg, 2012). It is a process that guides and empowers students to be successful and, when resources and support are in place, there is a positive impact for student retention and graduation (Bland, 2003). Other research has investigated conceptual frameworks surrounding advising practices, like Creamer and Creamer's (1994) framework that defines the task, identifies outcomes, and promotes development, which falls in line with the practice of developmental advising.

Research conducted about the advising profession from the perspective of the advisor highlighted that the discipline lacked uniformity in daily operations outside of the main role of advising students, and that advisors found themselves to be a legitimate part of students' experience beyond helping them with course selection, as long as the system is established to allow advisors to understand their purpose and direction (Aiken-Wisniewski, Johnson, Larson, \& Barkemeyer, 2015; Bridgen, 2017). As research continues to develop to discuss the role of advisors with high DE credit-earning students (Bennett, 2018; Shaw, 2019), it is still 
important to recognize the importance of advisors both generally and also to put their roles, advising challenges, and successes in context.

\section{Overview of Dual Enrollment}

The number of students enrolling in college full-time with college credits from concurrent and DE courses continues to increase (Thomas, Marken, Gray, \& Lewis, 2013) with the National Center for Education Statistics reporting 2 million DE course enrollments (Thomas et al., 2013). A growing body of research provides evidence that participation in these credit-bearing opportunities contributes to success in future college degree completion (Daly, 2009; Puyear, Thor, \& Mills, 2001; Rowett, 2012). These programs strive to improve access and better prepare students for the rigor of college-level coursework, particularly students from traditionally disadvantaged backgrounds (Barnes, Slate, \& RojasLeBouef, 2010; Conley, 2010). Dual enrollment can take many forms, with the common feature being simultaneous enrollment in high school and college courses (Fincher-Ford, 1997; Klopfenstein \& Lively, 2012). One of the most comprehensive models is early college, in which historically underrepresented students are enrolled in a rigorous program starting in the ninth grade and can finish an associate's or bachelor's degree within six years (Brewer, Stern, \& Ahn, 2007). The early college model has proven to be an effective way to increase high school and college completion rates as well as to have a positive impact on the students' high school experiences (Haxton et al., 2016). Other models focus on encouraging students enrolled in career and technical education to persist beyond the high school diploma (Lewis \& Overman, 2008).

The benefits of participating in these types of programs in high school include the opportunity to earn college credit at a much lower cost than the usual tuition cost and the availability of additional support while in the courses. Participation in DE programs often leads to better academic performance and reduces the need for remediation once in college, and these benefits are available to students regardless of their socioeconomic status (An, 2013). Many first-year students may see an improvement in their GPA if they enter college with DE credit (Smith \& Garton, 2008). 
For students in community colleges, DE credits can promote their academic momentum early in their academic careers, leading to greater persistence and degree completion (Wang, Chan, Phelps, \& Washbon, 2015). However, while DE credits may move students closer to achieving their college degree, it is not clear how students' non-cognitive learning and development is impacted, and thus, many academic advisors use their role to ensure students do not miss out on developmental opportunities because of previously-earned DE credits.

\section{Non-Cognitive Collegiate Outcomes}

There are benefits to a college education beyond the cognitive learning that happens in formal and informal classroom settings. Some of these non-cognitive outcomes include ethical behaviors and decisionmaking, an increase in civic engagement, character development, spirituality, enhanced collaboration and teamwork, improved interpersonal communication, stronger presentation and public speaking skills, and increased cultural competence (Liu \& Yin, 2010). Activities ranging from gardening to spiritual development can improve self-esteem, self-efficacy, and empathy (Capeheart-Meningall, 2005; Hoffman, Knight, $\&$ Wallach, 2007). Living on campus can also significantly improve noncognitive outcomes, including participation in discussions with diverse groups of people as well as increased engagement with collaborative learning compared to those who spend less time on campus (Graham, Hurtado, \& Gonyea, 2018). The length of time spent in higher education appears to have a cumulative effect on these non-cognitive outcomes, because seniors report more aggregate growth as compared to earlier points in their college careers (Kuh, 1993). Therefore, these non-cognitive outcomes of a college education may be less impactful for students who spend less time in a higher education setting, which concerns many development-focused academic advisors. 


\section{Theoretical Framework}

In this study, we used sensemaking theory to provide a framework for exploring how academic advisors approach the task of working with students with DE credit. According to Odden and Russ (2019), sensemaking is the process of constructing an understanding of ambiguous or unexpected situations in order to address a gap in knowledge or a misunderstanding. Sensemaking as a theoretical framework seeks to understand the elements involved in the process of how individuals and organizations make sense of these ambiguous situations and how they use that information in the future when facing the next ambiguous situation or identified gap in knowledge (Weick, 1995). Weick (1995) describes seven assumptions of sensemaking: the importance of the sensemaker's role, the centrality of retrospection, the interaction with a sensible environment, its social nature, its continuous process, the importance of extracted cues, and the guiding role of plausibility. In this study, we focused on the sensemaker's role, trying to understand how the uncertainty of working with students with DE credits impacts academic advisors' decisions; on the centrality of retrospection, encouraging academic advisors to look for patterns and meaning as they reflected on their experiences; and on the continuous process, as the academic advisors work in a field with a constantly changing clientele.

\section{Research of Design and Methods}

Because of the limited exploration of the experiences of this population and the advisors who guide them through their collegiate experience, as well as the desire to understand the meaning making of the participants, the tenets of constructivism guided the research (Creswell \& Creswell, 2018; Crotty, 1998). Researchers use constructivism to understand complex human phenomena (Broido \& Manning, 2002; Creswell \& Creswell, 2018), such as the experiences of unique, underexplored populations. The purpose of the study is to explore the DE perspectives of academic advisors in higher education who work with high credit-bearing incoming students and understand how they balance 
the importance of student development with students' possible desire to complete academic requirements in an abbreviated timeframe. Through this approach guided by constructivism, we sought to understand how academic advisors construct meaning of high DE credit-bearing students' experiences and needs based on their perspective of DE enrollment (Creswell \& Creswell, 2018).

Upon receiving IRB approval to conduct the research, this study employed a qualitative research design to explore perspectives of 11 academic advisors (Table 1 ) recruited through a statewide network (NACADA regional listserv) and direct emails to advisors in the state. The participant request yielded representation from seven institutions in the state. In order to participate, academic advisors must have advised students at a four-year institution in the state who earned 24 or more DE credits during high school prior to entering college. Participants received a $\$ 25$ Amazon gift card as an incentive to participate.

Constructivists focus on the participants' perspective and seek to understand how the participants' interactions with others developed their views (Creswell \& Creswell, 20018). In accordance with constructivist research, this study employed 30-45 minute semi-structured interviews to gather data from participants to ensure focus on participants' perspectives (Crotty, 1998; Mertens, 1998; Salmons, 2015). The structure of the interview questions encouraged participants to make meaning of their experiences and perspectives working with high DE credit-bearing incoming students. Sample interview questions included:

1) What has been your experience advising/working with students directly from high school who enter college with at least 24 credit hours (typically sophomore standing)?

2) What do you see as the academic and developmental value of students participating in DE classes before coming to college?

3) How do you utilize your understanding of student development in your advising practice?

Prior to data collection, a member of the research team with five years of experience similar to that of the participants reviewed the interview questions to ensure clarity and the ability to generate thick 
description of participants' perspectives. The researchers understood how their experience with the DE phenomenon could influence their analysis and allowed the participants' worldview to emerge throughout the research process.

Once the data was collected and transcribed, an inductive coding approach was employed (Miles \& Huberman, 1994), and the researchers independently reviewed the data for emergent themes. The researchers, both those with experiences with DE students and those external to hands-on experience with DE students, agreed upon the main themes after individually developing them and comparing their codes to developed final themes from the data.

\section{Table 1. Particpants}

\begin{tabular}{|c|c|c|c|}
\hline Pseudonym & Advising Experience & Institution Type & Academic Area \\
\hline Alice & 2 years & comprehensive public & art, music, theatre \\
\hline Bailey & 10 years & comprehensive public & general \\
\hline Eleanor & 4 months & public research & STEM \\
\hline Hilary & 6 years & comprehensive public & $\begin{array}{l}\text { business/health } \\
\text { sciences }\end{array}$ \\
\hline Jim & 12 years & regional comprehensive & nursing \\
\hline Lacey & 22 years & public research & $\begin{array}{l}\text { psychology/ } \\
\text { neuroscience }\end{array}$ \\
\hline Leticia & 6 years & public reserach & nutritoin \\
\hline Lucy & 2 years & regional comprehensive & general \\
\hline Nick & 6 years & comprehensive public & $\begin{array}{l}\text { engineering/ } \\
\text { business }\end{array}$ \\
\hline Sophie & 7 years & public reserach & $\begin{array}{l}\text { engineering/ } \\
\text { biomedical science }\end{array}$ \\
\hline Trey & 4 years & comprehensive public & general \\
\hline
\end{tabular}

\section{Findings}

Academic advisors play a key role in students' college experience as students navigate degree requirements. Advisors also serve as an ongoing 
resource for referrals related to student retention needs, such as financial aid, career development, and co-curricular opportunities. The findings include understanding how advisors' philosophy of higher education informs their approach to advising, advisors' role in explaining college curriculum to students with DE credits, how they present options to students to enhance the college experience, and advisors' approaches to addressing academic and non-cognitive preparedness concerns.

\section{Philosophy of Higher Education Informs Approach to Advising}

Participants' philosophy of the purpose of a college education informed their practice as they advised high DE credit-bearing incoming college students. Advisors shared a common view of higher education that must be explored to understand why they advised this student population as they did. Overall, advisors viewed college as more than credit attainment toward an academic degree; college is an opportunity for students to develop psychosocially and cognitively as well as learn about themselves to inform future decisions.

Developing purpose. While employment and finding a career are important roles of higher education, in line with Chickering and Reisser's (1993) Seven Vectors of Identity Development, advisors viewed work more broadly and thus saw higher education as a place to discover passions to align with a career. Alice stated:

Ideally, college is a place where students can figure out what they're passionate about, what they can be doing long term that will pay the bills but also will give them something that they're excited to do every day. That's a little bit idealistic. Probably a lot of it is just to get them skills that they need to get a job. But especially in the fields that I'm working with...in the art, music and theater, trying to help students hone in on what that passion is and figure out how to make that a realistic career. And then also along the way, hopefully they're getting other opportunities that are helping them sort of widen that world view and expand their perspective.

Hilary agreed with Alice in the view of college as a place of discovery.

I think the purpose is for students to elevate themselves to have more knowledge about what they're interested in or what they have 
a passion for. I don't feel that the purpose is degree completion. I feel like it's part of their journey in figuring out what they want to maybe do in life or discovering things about themselves, as whether being a student is the right fit for them. Maybe they have goals that they're able to achieve and maybe those goals end up changing, but I think it's a stepping-stone in life that can be a catalyst into decisions they make moving forward.

Pursuing a purpose set forth prior to enrolling in college, developing a new purpose, and altering an original professional or personal purpose is part of the college experience that advisors hope students will experience as young adults.

\section{Development of problem solving and critical thinking skills.} Higher education's foundation is the pursuit of knowledge and advisors echoed this statement in their view of its purpose. Not only was knowledge attainment important to participants, but so were other aspects of cognitive development, including developing critical thinking skills and how to solve problems without clear answers available.

Trey believed that "there's a two-fold purpose of higher education in reality. It's advancing the cognitive development of individuals and the knowledge." Jim noted differences between high school and college in terms of the focus on developing critical thinking skills:

I also believe that higher education is an opportunity for individuals to think outside the box. In high school, you're taught here's what you got to know and then you just go recite it. Here's what you need to know, and then you just study the sheet and you take a test. In college, students are challenged. They have to become critical thinkers. If they don't like something, then tell me how you fix it. What would you do to fix it?

Nick provided a specific example of the heightened critical thinking abilities that students develop in higher education. "Working with first year students specifically, I reinforce that societal expectations of a college graduate, that you are able to quickly somewhat effectively evaluate opinions for validity or recognize logical errors, or even questionable logic or research." 
Sophie shared in the views of other advisors in the purpose of higher education related to cognitive development:

I think the purpose is to educate, but it's also not necessarily to just to give all the answers, but to help students learn how to use those skills like critical thinking and problem solving, kind of navigating those pieces, versus $\mathrm{X}+\mathrm{Y}=\mathrm{Z}$. That kind of stuff is easy enough to look up, but it's how do you know where to look? How do you know how to make sense of that in the context of what it is that you're doing? The questions advisors shared provide tangible approaches of ways to enhance students' critical thinking, one of their stated purposes of higher education.

Time to mature. Beyond skill development as an important outcome of a college education, advisors found college as a time to grow and mature as students learn about themselves and the world around them. Lacey stated:

College is a process of self-growth and self-awareness. I quite often have said to students in advising appointments that I really view their journey [in college] to be way more than what goes on in the classrooms or in the hallways of academia. That it's just as much about learning how to just deal with disappointments and negotiate challenging systems and large systems. Really learning how you react to things and just how to navigate the world and how to deal with roommates and communication.

Lacey believed a multitude of changes happen to students in college and Jim agreed on the development necessary in college.

Then, there's also the social development perspective, especially if you talk about traditional age college students. I feel there's the social developmental aspect that, in partnership with the knowledge acquisition, there's that developing accountability, responsibility, autonomy, self-authorship, all that stuff that as adults we almost forget about from our college experience, if we're lucky enough to go to college. I feel the role of higher education is really a holistic endeavor, in that it's not only to advance knowledge and understanding, but also development and growth. 
In practice, advisors were open with students about their view of higher education and how the expectations of incoming high DE credit-bearing college students' use of their credits could influence other non-academic aspects of their development. For example, advisors explained how these circumstances could possibly impact students' ability to fully experience college and the developmental aspects of the experience. The remaining findings describe advisors' approaches to advising incoming college students with high DE credits from high school, which are informed by their beliefs about the purpose of the college experience and a higher education degree.

\section{Explaining College Curriculum}

An important role of academic advisors with all students they work with is to explain degree requirements and how specific courses lead to earning a degree. Participants described how high DE credit-bearing students may not understand how the credits earned in high school count towards a specific major, which led to students' disappointment and frustration. Other situations advisors described were students taking DE courses that were counted as electives in their college degree plan, which led to students having challenging semesters without buffer courses to lighten the overall rigor of the semester. Advisors were concerned with how students were advised about which DE courses to take and spent time after the DE courses were completed explaining the influence of the courses on students' college curriculum and degree attainment. While this can frustrate students, it was important to teach them to critically examine their academic plans as well as respond to adversity when situations have different outcomes than they expected.

Lucy provided a specific example of the concern and her role as an advisor to explain the DE course impact and demonstrate the type of questioning used when working with students to ensure they are goaloriented.

Sometimes their credits are all over the place. I wonder if somebody guided them, or said 'Okay, this is your major.' Or 'this is what your goal is.' Or even did goal planning. Or if was just 'Oh these classes 
work with your schedule, you have to be at the school at this time, so let's put you in all these classes in the afternoon.' And you're like, 'why do you have these classes?' A lot of students are in Calculus $2 . .$. are you going to be like an actuary? Are you going into business? Are you teaching? And they are like, 'No, I want to be a social worker.' I don't know, sometimes with some of these students, you wonder who guided them before they got to you.

Nick experienced the same situations with students who were seeking a business degree, which at his institution, has a defined degree plan. The first is a general understanding of how an undergraduate curriculum is set up. Specific course requirements versus overall credit hours. Since they're not generally working with an academic advisor, no one has really explained that to them. And I honestly question if the teachers teaching these courses comprehend that as well. So they come in with high expectations that I have 30 hours, I'm going to be able to graduate a year early, and often are met with disappointment when they learn that maybe in a different program, but not Business. So that is one disadvantage. They seem to be overpromised and the university gets stuck with the hard message that it's not necessarily true.

Trey summarized the situation Lucy and Nick discussed.

I'm running into quite a few students right now who are just taking credits for the sake of taking credits to meet their high school requirement, upper level requirements, and they're not fitting into their career plans as easily. They're coming in almost with excess credit.

The major challenge regarding DE course credit typically involved students pursuing a specialized degree as Trey noted:

There's really technically no such thing as one-size-fits-all general education requirements for any of our degrees. I mean, every degree is very specific in what they want you to take for your general education requirements. They have them built in. If you want to do one of the more non-liberal arts-based majors, like business or aviation or any of the engineering programs, you're going to be 
looking at a different general education setup, unless you want a liberal arts degree. Now, the students who are bringing those excess credits and are looking at a liberal arts major, wonderful, because then we can make use of all of those credits that they're bringing it. Whereas, again, if they want to go into a more specialized degree or specific degree, then it's kind of a struggle.

He found, however, that when the courses were sporadic, that the student may not have a focus on their career goals either, so DE courses were used as major exploration as well. As an advisor, Lucy, Nick, and Trey focused on teaching their advisees that courses required for a major are purposeful and discussed with students the relevancy of DE courses to their intended degree.

Bailey described how students with high DE credits may prepare for a meeting with an academic advisor and how she approached the discussion.

But when it's more like two years worth of college, or a year and a half or something, they often will come in with an Excel file that's mapped out every term until graduation, or maybe potential transfer courses, like they have a map and so they have a very set expectation I think. Sometimes, when we have to deviate from that, it's a little concerning to them.

DE students have developed an understanding of the curriculum, but it may not be to the level of understanding that considers not only the courses to take to complete a degree, but also the implications of that plan.

Hilary echoed the concerns about a lack of intentionality surrounding DE course enrollment and noted how when that occurs, there are implications that lead to a challenging structure of courses.

A lot of students we have come in have 60 hours. They've been working towards their associates and they expect to graduate in two years. The hard thing is, with business, it was pretty clear they could do that. They have the right classes to take. What's hard now with the majors I advise for, is they have taken 60 hours but they're not the right 60 hours to graduate in four years. So, it's a hard conversation to have is, okay, we're really starting with freshman level courses and 
now we have to talk about course sequencing. And even though I can write down on paper and get you out of here in, maybe, three years, it's an impossibly hard schedule. It's not going to be fun, probably not realistic, but I'll do what you ask and draw it out for you. And then we'll talk it out after you've had your first semester and see how you're going to feel.

Sophie shared Hilary's concern about rigor once DE courses are completed:

Most people just don't understand enough about the curriculum to be able to appropriately make those decisions and look at those courses. It's not necessarily a great idea to have an Associate's Degree before you get here. Then you're running into all sorts of other issues of now all your semesters are so heavy sciences, heavy labs that you're putting yourself into a position where you're struggling in your classes because you don't have anything to balance it out. When they have concerns about the rigor of schedules due to DE credit impact, Hilary and Sophie's approach involved reevaluating the rigorous academic plan to better determine students' abilities to be successful. Advisors' approaches to explaining college curriculum and the implications of DE credit on degree completion consistently included concerns about students' ultimate academic performance and success in college. They approached their advising practices with the goals of helping students understand college degree plans and consider how to balance out each semester's schedule to ensure it is manageable.

\section{Presenting Options}

Advisors' approaches to assisting students in making strategic choices about their education included providing various options as well as the benefits and challenges that accompany each option. Because of limited college advising focusing on the impact of DE course credit while the students were in high school, college academic advisors frequently discussed the implication of students' DE credits and then presented options students may not have previously considered. In congruence with their stated purposes of higher education, participants often encouraged 
students to reframe their plans for an expedited degree plan, which was often only for short-term financial gain, in order to ensure college outcomes beyond obtaining a degree were met.

Leticia discussed her approach to providing students with options knowing that advisors lack real power over students' academic decisionmaking, but they hope to have a positive influence:

At the end of the day, for any advisor, I can't make a student do anything. But I can present to them all the facts, all what I know, based off my experiences working with students, and offer them recommendations of how I think they should move forward. I think my approach is that this is their experience. Their choices. Their right to make whatever decisions they want to make, even if I feel like it may negatively impact them. I can't force them to take certain classes...I try to be transparent. I let students know, 'hey these are things that you're missing out on by graduating early. You're not going to have time to do some of these things. And I think you're going to be under a higher level of stress than really may be necessary for you to be. That having these extra credits will allow you to be able to add a minor, or to add another something that might be of interest to you that you may not have been able to do because you didn't come in with all these credits. Just presenting it that it might be long term better for you to be here an extra semester.

Leticia worked to encourage students to take full advantage of the college experience that DE credits allow instead of the idea that DE students often present to her about wanting to complete college quickly. Sophie used the phrase "parallel planning" in her work with students to encourage them to consider options beyond their initial goal in the event that they were not able to achieve it.

I'm a big proponent of parallel planning. Just kind of looking at what other options. I intentionally use the phrase, parallel planning versus plan B because I think especially with that population, students hear plan B and they're like, oh, you think I can't go to medical school. I'm like, that's not what I said at all. I think maybe right now we need to look at a couple of different options, so if you apply to medical school 
and you don't get in, which is moderately likely, what are you going to do to make yourself a good applicant for the long term?

Trey found that incoming college students with a high number of DE credits from high school often sought out their entire degree plan in their first advising appointment because they had specific goals or plans for their time in college. He stated that he would first say, “That's a wonderful goal. Let's plan it out."' Then, he would:

Try to map it out as far as we can, so I do a lot of what-if reports. Then, we do a map-out, saying, 'Okay, this is your goal. If you want to do that, here's what you need to do, meaning sometimes you may not have summer vacations. It's going to be continuous school. You may burn out.' This is the reality of the situation.

He hoped by providing students with an alternate reality based on their goals that they would make informed decisions because he often presented them with information about their degree plans of which they were unaware.

Many times, Jim's options for high DE credit-bearing students involved ways to slow down their time to degree, which based on the purposes of higher education advisors shared, would indicate that DE students need more time in their bachelor's degree environment to achieve goals of college beyond their degree:

I try to put things into perspective. The one thing that my students, if you've ever met one of my students whose worked with me they'll tell you, what about me is I'm $100 \%$ honest. For a student that developmentally wants to get through it, I try to put things into perspective and just ask them questions about, 'What are you going to do? What are you going to do afterwards? What's going to happen?' I try to get into their head a little bit to see what they're thinking is on the other side of the fence versus what really is on the other side of the fence, and then how can I meet them in the middle to help them maybe slow it down a little bit or even think, okay, 'if you get done early, then what's next?'

Eleanor saw DE credits as a way for students to "lighten their load throughout that four years when they already have some knocked out. 
They can take one class less each semester." The technique of encouraging students to slow down their intended timeline was a common approach among advisors in the study. Interestingly, students seek to speed up their timeline for financial benefit, but the advisors were never interested in the financial gain of the institution as reasoning for their recommendations. Rather, they were consistently focused on the best developmental experience for their DE students.

Sophie described specific questions she asked students to encourage them to consider their options in college particularly because of the DE credits, which allow for additional flexibility.

Even just thinking about, if you're coming in and you could graduate a year early, 'what about double majoring? You've always liked history. Why not do a double major in biological medical sciences and history? With that extra year, you've got plenty of time to throw in all those courses.' It gives your brain something different through all those other semesters, so we're not looking at such heavy science semesters.

Advisors' experience with this population is that many students are seeking the fastest time to degree before considering what is required to do so, as well as what may be missing if their full-time college student experience is truncated. Ultimately, advisors encouraged students with DE credits to make the most of the collegiate experience by using the credits to their advantage over the typical four-year college timeline. This included ideas such as pursuing another academic interest and decreasing stress levels by taking one less course a semester.

\section{Supporting the Transition from High School/DE Student to Full-Time College Student}

An important role of academic advisors is preparing students in a developmentally appropriate way to take responsibility for their education. Advisors must help students move from others telling them what to take in terms of coursework to being more independent by completing their own academic planning. Trey shared:

I would say nine times out of 10 , it's unrealistic. They think just 
because you're coming in with 24-plus credits, that they should be closer to being done with a degree. Through that whole experience, they've been told, 'Well, this is great. You're getting college credit for it,' with, again, no understanding of intentionality behind the credit that they're taking or the whole understanding of academic planning. They're still at that point where they're relying upon their guidance counselors and their parents to tell them what to take. Then, they get to an advisor and they're like, 'What do you mean I have to plan my own courses?' They're so used to a different structure.

Although students may have taken DE courses, which are college-level courses, the expectations around their ownership of the DE experience may not have been the same level of expectation as advisors have for full-time college students. Thus, advisors considered how to support DE students who may have seen success in college-level academic courses but were not independent in terms of their involvement with DE.

\section{Advising Approaches to Addressing Academic Preparedness Concerns}

Advisors presented concerns about the differing levels of preparation that occurs in the various ways DE credit is earned: some in the high school taught by certified high school teachers; courses in the high school with a college-level instructor; and lastly, students attending class at a college or university alongside full-time college students. While the DE credit may count toward a degree, the foundation may not have sufficiently prepared the student for the rigor of college-based courses. Advisors consider the possible disconnect in their advisement of students because they do not view the number of credits as a single indicator of readiness.

Because the ultimate goal of DE is not that of saving money, although that seems to be a major part of the narrative about why students enroll in DE courses, Eleanor shared concerns about preparedness:

However, in my students back home who have that struggle academically already, I feel like them taking the English class at the high school but getting college credit for it is not at all going to transfer over to the college, and I feel that it's not benefiting them. It's 
saving them money and I understand that, but just them learning the material and the rigor at a university or college, it's definitely not the same.

Sophie shared a specific example of advising about preparedness considering not only DE but also AP credit:

I'm usually having long conversations with them about whether or not it's a good idea to repeat some of those classes or not because sometimes they're doing it to try to save money, which I totally understand. If you're not getting a solid foundation in Biology from the AP Biology for example and going into a Biology major, then I want you to retake the course.

Nick also noted other college credit granting approaches, not just DE courses, that led to preparedness concerns:

Working with engineers for the past four years, students coming in, even having credit for Calculus 1, I got to the point that I recommend they re-take it, if for nothing else to level set the expectations to their specific institution. Whether they took that in high school, whether they took that in AP, whether they took it at a community college, I've kind of reached the point that I recommend that even if they have credit, that they re-take Calculus 1 to help with that transition. The same is true in the natural sciences as well. Students in my programs have often struggled with the jump from even credit-bearing math and sciences courses to the collegiate level. And that is often due more to pace than anything.

Each of these advisors addressed their concerns about preparedness with their students with DE credits to ensure they continued with their degree progress as opposed to being unnecessarily challenged because of a lack of preparedness from DE coursework.

Eleanor not only considers the preparedness from DE courses at the beginning of students' college careers, but also throughout their degree progress. If a student who brought in DE credit is struggling, she ensured that it was not a preparedness issue.

I would say it's the same as advising all students, just checking in and seeing how they are, but with these students I guess just making sure 
you put Calc closer to starting college since that may have been in their junior year. So definitely just checking in on those courses where they might have gotten credit from a while ago. Again, that math and science, that's the foundation for everything, so just paying attention to what credits they brought in and making sure that those are the classes that they're not struggling in.

From Sophie's experience at a state institution that drew many students from a specific community college, she noted a trend and used that to the benefit of future students.

There's a couple that I know are coming in with a Biology class from a particular community college up here that they're not well prepared for our courses and they'd be much better served by retaking that course even though it's going to be spending a little of extra money. It might not necessarily be a super difficult course for them. They're not entirely poorly prepared. They're just not prepared at the same level that our students are.

Advisors consistently wanted the best for students while recognizing the additional financial burden on retaking courses, but advisors felt it was a way to better prepare students for success, which could have greater financial implications if they are unable to complete their degree or pursue a degree or career field of choice. Students' intellectual competence (Chickering \& Reisser, 1993) developed in DE coursework was a consistent concern for advisors, and as a result, advisors sought to ensure academic success by being proactive when they had concerns about academic preparation.

\section{Advising Approaches to Non-Academic Preparedness Concerns}

Advisors were not just concerned with academic preparedness, but also how other aspects of the college transition may impact academics. Although students with DE credits may feel prepared to achieve academically, they have not done so as a full-time college student with the other new responsibilities of living away from home.

Nick's perspective about teacher-led and student-led learning highlights a difference between the college and high school experiences. 
Academically, the students with these types of experiences, whether AP, IB, or actual concurrent enrollment courses, they transition in the classroom a little better. They are more prepared for the rigor, but as I've alluded to, they may not be ready for full time university enrollment. There is something maybe about the setting, the class format, the pace of the class, the instructor's involvement, maybe even the size of the class that can catch students off guard, even students with over 24 hours that if they were taking the courses with a high school instructor in their high school. They don't necessarily make that distinction and recognize the change in responsibility from teacher-led learning to student-led learning.

Leticia also noted the confounding responsibilities on students that advisors consider when working with students seeking to move ahead academically in college because of their DE credits.

You're not prepared to take these courses yet, because of just the adjustment you're going to have in terms of being on a college campus. Living in a residence hall, there's all these personal things that are happening on top of you being in this courses that are going to be super rigorous. So, I have to make a call in trying to convince the student, hey please don't take Organic Chemistry and Physiology together. Even though you have the prerequisite to do so, you will not be successful. Students may have an over-confidence in their abilities because of their DE credits.

Hilary shared:

I think the biggest thing is, honestly, trying to advise them on having a little humility because they feel like ... they know they're ahead of the game, so they feel like they are so ready and they're so much more knowledgeable than their peers. Which is true, however, there's also some things that they are not quite up to par with. One example is, we have a lot of our high school DE students come in, already completing their first year of chemistry, for example. Coming in as technically a freshman, they're wanting to take Organic Chemistry, which is a junior level course for our traditional students who come in. And they, academically, can enroll for it and are technically ready for it, but a lot 
of them really struggle jumping right into 0 Chem their first actual semester of college. And they have a hard time sometimes hearing that because they just want to move forward in the next step. I don't feel like, based on my experience with other students that have gone

through it, they're not ready for that.

When considering advisors' role in students' college coursework plan, quantitative data known about DE students and their transition to higher education may be skewed without this qualitative understanding of the advising process. If the students chose courses completely on their own accord without advisement, the data may not be as positive. Academic advisors are influencing the decisions of DE students when they arrive as full-time college students, and their involvement in DE students' success must be considered.

\section{Discussion and Implications for Practice}

With any educational policy, while it may bring about a positive solution to some problems, it may also create additional challenges that were not initially considered. With DE, the literature surrounding the benefits of participation is clear and demonstrates to students at an earlier age that they can be successful in college on a smaller scale before arriving on campus full-time, which improves access to higher education (An, 2013). As demonstrated by the academic advisors in this study, there are multiple considerations when students who have been successful in DE courses come to college full-time because there are frequently gaps in students' and families' understanding of how DE credit influences degree completion beyond achieving the number of credits needed to graduate from college.

Many of the concerns surrounding students with DE credit involved students' and families' expectations for an expedited college career because of the development that occurs in higher education in conjunction with the academic degree attainment. Advisors noted frequent discussions with students about the ability to complete within their truncated timeline, which students often created with the goal of 
conserving financial resources. To improve the experience of students by managing their expectations of $\mathrm{DE}$, intentional dialogue is needed between the community colleges, K-12 system, and the state universities around the messaging to students and families about DE benefits and implications. Initially, improving advising practices for high school students considering DE participation, either by high school counselors or college academic advisors, would allow students to understand the meaning behind college credit and the implications of DE course completion on their college experience. Providing an orientation to DE students about college curriculum and degree plans in higher education would provide students with more information so that when they meet with a college academic advisor as a full-time college student, this meeting is not the first time they are hearing concerns about preparation from DE coursework or how their degree timeline may not be as quick as initially expected.

Student development and maturity were major concerns for academic advisors in the study because they were unsure of DE students' ability to address academic challenges often not experienced until the second or third year of college, manage independent living and the social pressures of college while pursuing a rigorous course load, and be successful post-college in work and graduate school endeavors. While many academic advisors are trained in the foundations of student development, as DE offerings expand across the U.S., additional training would prepare advisors to work well with students with a high number of DE credits as those students enter college. Many DE students are degreeand career-focused, so focusing on career exploration early in the advising relationship may be appreciated by students who feel they are closer to degree completion than an incoming student starting college credits from the beginning.

In addition to discussing college curriculum requirements and how to complete an academic degree, based on the advisors' view of the purpose of higher education, intentional discussion about purposes of college beyond degree completion is necessary for students to understand the value of involvement on campus, as well as the unique opportunities in which they are able to engage during college to prepare them for 
their future career and graduate school interests. College is a time for developing purpose (Chickering \& Reisser, 1993). While often focused on the financial commitment necessary for a college degree, families must also understand the importance of involvement, exploration, and development for their student to fully promote that student's ability to be successful after college.

\section{Conclusion}

While there are elements of individualization in academic advising settings with all students, when working with high DE credit-bearing incoming students, academic advisors took an even more individualized approach based on each student's academic progress, goals, and preparation factors. These students' schedules were more specialized, and the students were frequently interested in long-term plans as opposed to focusing on a semester or year at a time. Overall, incoming students with high DE credits have unique expectations of the college experience and both professional and faculty advisors should be prepared to provide developmentally-focused guidance to enhance the full-time college student experience.

\section{References}

Aiken-Wisniewski, S. A., Johnson, A., Larson, J., \& Barkemeyer, J. (2015).

A preliminary report of advisor perceptions of advising and of a profession. NACADA Journal, 35(2), 60-70.

An, B. P. (2013). The influence of dual enrollment on academic performance and college readiness: Differences by socioeconomic status. Research in Higher Education, 54(4), 407-432.

Barnes, W., Slate, J., \& Rojas-LeBouef, A. (2010). College readiness and academic preparedness: The same concepts? Current Issues in Education, 13(4).

Bennett, E. B. (2018) Exploring the growth of dual credit education in Texas, (Master's thesis). Retrieved from Texas State University Collections. (Accession No. 2018-04-30T14:16:28Z). 
Bland, S. M. (2003). Advising adults: Telling or coaching? Best Practices, 6-9.

Brewer, D. J., Stern, S., \& Ahn, J. (2007). An introduction to "early college." Education Finance and Policy, 2(2), 175-187.

Bridgen, S. (2017). Using systems theory to understand the identity of academic advising: A case study. NACADA Journal, 37(2), 9-20.

Broido, E. M., \& Manning, K. (2002). Philosophical foundations and current theoretical perspectives in qualitative research. Journal of College Student Development, 43(4), 434-445.

Capeheart-Meningall, J. (2005). Role of spirituality and spiritual development in student life outside the classroom. New Directions for Teaching and Learning, 2005(104), 31-36. doi:10.1002/tl.210

Chickering, A. W., \& Reisser, L. (1993). Education and identity (2nd ed.). San Francisco: Jossey-Bass.

Conley, D. T. (2010). College and career ready. San Francisco, CA: Jossey-Bass. Creamer, D. G., \& Creamer, E. G. (1994). Practicing developmental advising: Theoretical contexts and functional applications. NACADA Journal, 14(2), 17-24.

Creswell, J. W., \& Creswell, J. D. (2018). Research design: Qualitative, quantitative, and mixed methods approaches (5th ed.). Thousand Oaks, CA: Sage.

Crotty, M. (1998). The foundations of social research: Meaning and perspective in the research process. London, England: Sage.

Daly, D. D. (2009). The relationship between college-level learning in high school and post-secondary academic success (Doctoral dissertation). Retrieved from ProQuest Dissertations and Theses database. (UMI No. 3356021).

Fincher-Ford, M. (1997). High school students earning college credit: $A$ guide to creating dual-credit programs. Thousand Oaks, CA: Corwin Press.

Graham, P. A., Hurtado, S. S., \& Gonyea, R. M. (2018). The benefits of living on campus: Do residence halls provide distinctive environments of engagement? Journal of Student Affairs Research and Practice, 55(3), 
255-269. doi:10.1080/19496591.2018.1474752

Haxton, C., Song, M., Zeiser, K., Berger, A., Turk-Bicakci, L., Garet, M. S., .. . Hoshen, G. (2016). Longitudinal findings from the early college high school initiative impact study. Educational Evaluation and Policy Analysis, 38(2), 410-430. doi:10.3102/0162373716642861

Hoffman, A. J., Knight, L. F., \& Wallach, J. (2007). Gardening activities, education, and self-esteem: Learning outside the classroom. Urban Education, 42(5), 403-411. doi:10.1177/0042085907304909

Klopfenstein, K., \& Lively, K. (2012). Dual enrollment in the broader context of college-level high school programs. New Directions for Higher Education, (158), 59-69.

Kuh, G. D. (1993). In their own words: What students learn outside the classroom. American Educational Research Journal, 30(2), 277-304. doi:10.2307/1163236

Lewis, M. V., \& Overman, L. (2008). Dual and concurrent enrollment and transition to postsecondary education. Career and Technical Education Research, 33(3), 189-202.

Liu, Y., \& Yin, A. C. (2010). Assessing personal growth. New Directions for Institutional Research, 2010(S1), 111-123. doi:10.1002/ir.334

McMahan, A. B. (2008). How to become an academic advisor. NACADA Clearinghouse. Retrieved from https://nacada.ksu.edu/Resources/ Clearinghouse/View-Articles/Become-an-Advisor.aspx

Mertens, D. M. (1998). Research methods in education and psychology: Integrating diversity with quantitative and qualitative approaches. Thousand Oaks, CA: Sage.

Miles, M. B., \& Huberman, A. M. (1994). Qualitative data analysis: An expanded sourcebook. Thousand Oaks, CA: Sage.

Odden, T. O. B., \& Russ, R. S. (2019). Defining sensemaking: Bringing clarity to a fragmented theoretical construct. Science Education, 103(1), 187205. doi:10.1002/sce.21452

Patton, L. D., Renn, K. A., Guido, F. M., \& Quaye, S. J. (2016). Student development in college: Theory, research, and practice (3rd ed.). San Francisco, CA: Jossey-Bass. 
Puyear, D., Thor, L., \& Mills, K. (2001). Concurrent enrollment in Arizona: Encouraging success in high school. New Directions for Community Colleges, 2001(113), 33.

Rowett, C. (2012). Exploring college readiness: The role of dual enrollment and SES on college persistence and student success. (Doctoral dissertation). Retrieved from ProQuest Dissertations and Theses database. (UMI 3543604).

Salmons, J. (2015). Qualitative online interviews (2nd ed.). Thousand Oaks, CA: Sage.

Shaw, A. L. (2019). Tennessee high school counselors' and dual enrollment advisors' perceptions of student readiness for dual enrollment, (Doctoral dissertation). Retrieved from Electronic Theses and Dissertations. (Paper No. 3554).

Smith, A. R., \& Garton, B. L. (2008). Prior college credit of first semester freshmen: Does it make a difference? NACTA Journal, 52(3), 39-45.

Thomas, N., Marken, S., Gray, L., \& Lewis, L. (2013). Dual credit and exambased courses in U.S. public high schools: 2010-11 (NCES 2013-001). U.S. Department of Education. Washington, DC: National Center for Education Statistics. Retrieved March 8, 2017 from http://nces. ed.gov/pubsearch.

Wang, X., Chan, H., Phelps, L. A., \& Washbon, J. I. (2015). Fuel for success: Academic momentum as a mediator between dual enrollment and educational outcomes of two-year technical college students. Community College Review, 43(2), 165-190. doi:10.1177/0091552115569846

Weick, K. E. (1995). Sensemaking in organizations. Thousand Oaks, CA: Sage.

White, E., \& Schulenberg, J. (2012). Academic advising-a focus on learning. About Campus: Enriching the Student Learning Experience, 16(6), 11-17. 